\title{
POROVNANIE MODÁLNYCH ANALÝZ MEMBRÁNOVEJ KONŠTRUKCIE
}

\section{THE COMPARISON OF THE MODAL ANALYSIS OF A MEMBRANE STRUCTURE}

\author{
Lenka Štulerová ${ }^{*}$, Lukáš Kapolka $^{1}$, Stanislav Kmet ${ }^{1}$
}

*lenka.stulerova@tuke.sk

${ }^{1}$ Technická univerzita v Košiciach, Stavebná fakulta, Ústav inžinierskeho stavitel’stva, Vysokoškolská 4, 04200 Košice

\begin{abstract}
Abstrakt
Tento článok sa zaoberá porovnávaním výsledkov vlastného kmitania. Ide o membránu, ktorá v jednom prípade predstavuje osamotenú, kíbovo podopretú konštrukciu, v druhom prípade je táto konštrukcia doplnená o ocel'ový rám, do ktorého je uložená. Vo všeobecnosti sa pri výpočtoch zjednodušujú okrajové podmienky, avšak pri dynamike môžu tieto priblíženia negatívne ovplyvnit' skúmanú problematiku. Preto prvý variant prezentuje zjednodušenú formu a druhý variant presnejšie dopĺn̆a predstavu o reálnom modeli. Sledovanými charakteristikami a vlastnost’ami sú základné dynamické parametre: vlastná frekvencia, vlastná perióda. Ciel’om tohto príspevku je porovnat' vplyv okrajovej konštrukcie tvoriacej podperný systém na celkovú tuhost', ktorá sa môže značne podiel'at' na výsledkoch v rámci dynamických analýz.
\end{abstract}

\section{Kl'účové slová}

Membrána, modálna analýza, vlastné kmitanie

\section{Abstract}

This article deals with the comparison of the results of a natural oscillation. It is a membrane, which in one case represents a solitary, articulated structure, in the other case this structure is anchored to a steel frame. In general, boundary conditions are simplified in the calculations, but in dynamic specifically these approximations can negatively affect the results. Therefore, the first variant presents a simplified form and the second variant more accurately complements the real model. The observed characteristics are the basic dynamic parameters: natural frequency, natural period. The aim of this paper is to compare the influence of the secondary structure forming the support system on the overall stiffness, which can significantly contribute to the results of dynamic analyses.

\section{Key words}

Membrane, modal analysis, natural vibration

\section{1 ÚVOD}

Aktuálnym trendom v stavebnom odvetví sú čisté línie, vel'kost', jednoduchost' a vzdušnost'. Tieto parametre platia nie len pre architektúru a dizajn, ale sú rovnako žiaduce aj v konštrukciách samotných. Spolu s tým súvisia aj neustále sa zvyšujúce požiadavky na ekonomické navrhovanie a optimalizáciu. Tieto parametre výrazne vplývajú na súčasný výskum a vývoj materiálov. Uvedené skutočnosti vyústili k používaniu materiálov, ktoré majú vysokú tvarovú a priestorovú variabilitu, sú l'ahké, dostupné a ekologické. Práve medzi takéto materiály môžeme radit' tkanú textíliu - membránu.

Ide o materiál, ktorý pre svoje správne fungovanie využíva svoje prednosti v maximálnej miere a pri správnom návrhu zabezpečuje efektívnejšie využívanie. Hoci v svojej podstate nejde o inovatívny druh, nakol'ko sa textílie použivali už aj v minulosti predovšetkým na dočasné zastrešenia, podoba, v akej ju poznáme a navrhujeme aktuálne v súčasnosti má niekol'ko odlišných špecifík.

Základným rozdielom je nutnost' predopnutia svojej plochy, čo zabezpečí priestorovú tuhost' potrebnú na prenos rôznych druhov vonkajších zat’ažení - predovšetkým klimatických druhov zat'aženia. Predopnutie so sebou tak prináša dostatočnú únosnost', čo dovol'uje preklenutie pôdorysov rôznych tvarov a väčších rozmerov vytvárajúcich požadovaný otvorený priestor. Predopnutie je nutné aj vzhl'adom na fakt, že textilné membrány dokážu prenášat' zat’aženia iba v t’ahu, čím sa maximálne využíva ich potenciál. 
Nemožno opomenút' aj negatíva návrhu týchto konštrukcií, ktoré súvisia predovšetkým so správnym návrhom. V priebehu návrhu využívame proces form-finding, ktorý je typický pre t’ahané formy konštrukcií (nutný napr. pre lanové siete, ktoré fungujú na podobnom princípe), kedy sa hladá rovnováha medzi potrebným stanoveným predpätím a samotným geometrickým tvarom. Ide o inverzný proces, kedy poznáme výsledné žiadané predpätie, ale začiatočný tvar (presná poloha každého uzla tvoriaceho plochu membrány) je neznámy. V procese výroby je nutné byt' dostatočne presný aj pri výrezoch textílie. Inak to môže viest' k vrásneniu povrchu, čo vplýva na samotnú únosnost'.

Ako už bolo spomenuté, tieto konštrukcie, rovnako ako iné, je potrebné navrhovat' na klimatické zat'aženia ako sneh a vietor. A práve vietor je vel'mi významný faktor ovplyvňujúci navrhované konštrukcie najmä z dôvodu svojich dynamických účinkov. Preto ciel’om tohoto článku je základná analýza vlastného kmitania na vybranej konštrukcii. Práca sa zameriava na porovnanie a vyhodnotenie výsledkov modálnej analýzy na hyperbolickom paraboloide. Ide o 2 varianty konštrukcie: v jednom prípade predstavuje skúmaný numerický model konštrukciu membrány predopnutej pomocou okrajových nerezových lán a ukotvenej všeobecnými kíbovými podperami, zatial' čo v druhom prípade je táto konštrukcia rozšírená o podperný systém ocel'ových nosníkov, ktorý prezentuje reálne zariadenie v laboratóriu, na ktorom budú následne vykonávané skúšky a verifikácia s MKP modelom.

\section{POPIS SÚČASNÉHO STAVU A LITERÁRNY PREHLAD}

Dynamické pôsobenie na membrány/t’ahané štruktúry sa v rámci vedy a výskumu zameriava predovšetkým na pôsobenie nárazového zat’aženia od krupobitia, čo však nie je predmetom prezentovaného príspevku. Chanjiang Liu a kol. [1] sa venovali práve dynamickým účinkom od vetra na stabilitu sedlovej membrány. Zameriavali sa predovšetkým na účinok vetra vyvolávajúci galloping (trepotanie) membrány. Vytvorili postup na výpočet kritickej rýchlosti vetra, ktorý je závislý od pomeru vzopätia-rozpätia $\varepsilon$ a pomeru rozpätí $\lambda$. Pomocou parametrickej analýzy analytických príkladov je potvrdené, že ortotropia textílie (rozdielne hodnoty materiálových charakteristík tkaných membrán v dvoch na seba kolmých smeroch) a geometrická nelinearita má signifikantný vplyv vzhl'adom na jeho aerodynamickú stabilitu.

Najnovším príspevkom v oblasti dynamického vetra na membránach je článok Arjuna Kandel a kol. [2], ktorý skúmal odozvu vyvolanú pôsobením vetra na oválnu vzopätú membránu. Popísali odozvu membrány na zat'aženie vyvolávajúce kmitanie vzhl'adom na rôzne parametre: predpätie, smer a rýchlost' vetra, rozpon. Výsledkom bolo zistenie, že na odozvu vplýva predovšetkým nárast pomeru vzopätia a rozponu, avšak nie konštantne.

Yuki Takadate a Yasushi Uematsu [3], riešili aerodynamickú rovnováhu vel'korozponovej membrány použitím CFD simulácie. Porovnávali 3 typy zastrešenia a podrobnejšie skúmali kmitanie s uvážením interakcie konštrukcie s obtekajúcim tokom.

Vlastné kmitanie bolo ciel'om vedeckej práce Ali Reza Damercheloo a kol. [4], ktorí sa zaoberali modálnou analýzou kónickej membrány s rôznymi okrajovými podmienkami. Ortotropnú membránu a jej vlastné kmitanie skúmal X. H. Wang a D. Redekop [5]. 6 skúmaných vlastných tvarov ich priviedlo k porovnatel’ným výsledkom numerickej analýzy s MKP analýzou.

Meraniami na reálnej konštrukcii sa venoval Yue Yin a kol. [6]. Išlo konštrukciu pneumatickú, teda membrána bola predopnutá pomocou natlakovaného vzduchu. Pomocou systému kontroly bola reálna konštrukcia dlhodobá sledovaná a vyhodnocovaným bolo jej vlastné kmitanie dosahujúce hodnoty 0,273-0,457 Hz vlastnej frekvencie.

\section{METODIKA}

Na uskutočnenie modálnej analýzy bol použitý MKP softvér Dlubal RFEM. Základný model sa skladá z 2 konštrukcií: membrána samotná a stabilizujúce laná. Membrána je pripravená z 2 samostatných trojuholníkových prvkov spojených dolnou hranou a geometriou zobrazenou na Obr. 1 Geometria modelu. Základné materiálové charakteristiky sú uvedené v Tab. 1 Základné charakteristiky modelu.. V uvedených hodnotách modulov pružnosti membrány môžeme vidiet', že sa v jednotlivých smeroch 'x' a 'y' hodnoty líšia. Ide totižto o ortotropný materiál hr. $0,56 \mathrm{~mm}$, ktorý je charakteristický rôznymi vlastnost'ami v dvoch na seba kolmých smeroch, v akých bola tkanina tkaná. Smer 'x' je vedený medzi hornými vrcholmi a predstavuje hlavný smer osnovy. Smer 'y' predstavuje smer útku. Membránové elementy sú na základe nutnosti predopnuté pomocou nerezových lán prierezu $8 \mathrm{~mm}$ vedených v rukávoch po okraji membrány. Predopnutie je realizované v oboch smeroch membrány doplnené hodnotou absolútneho previsu lana.

Tab. 1 Základné charakteristiky modelu.

\begin{tabular}{cc}
\hline Charakteristika & Uvažovaná hodnota \\
\hline modul pružnosti membrány v smere 'x' & $1057 \mathrm{MPa}$
\end{tabular}




$\begin{array}{cc}\text { modul pružnosti membrány v smere 'y' } & 612 \mathrm{MPa} \\ \text { modul pružnosti lana } & 130 \mathrm{GPa} \\ \text { predpätie membrány } & 4 \mathrm{kN} / \mathrm{m} \\ \text { predpätie lana - previs } & 0,2 \mathrm{~m}\end{array}$
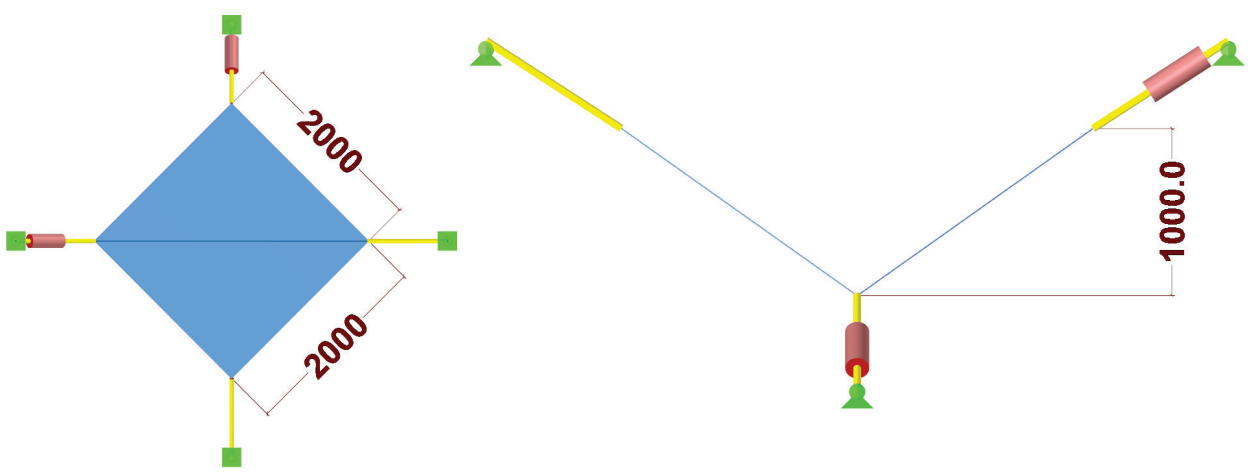

Obr. 1 Geometria modelu.

Model membránovej konštrukcie predstavuje reálne zariadenie. Toto experimentálne zariadenie má však použité aj akčné prvky - prvky, ktoré sa dokážu predlžovat' (znižovat' tak tuhost' membrány) a skracovat' (predpínat' membránu). Z hl'adiska použitia týchto prvkov v prezentovanom príspevku neboli uvažované, budú predmetom následného výskumu. Avšak kvôli svojej významnej vlastnej hmotnosti ich bolo nutné uvážit' ako hmotu v posudzovanom modeli, ked’že to vplýva na vlastné kmitanie. Na tento účel boli použité prvky D145. Aktuátory sa nachádzajú na 2 miestach hyparu, vo zvyšných 2 miestach je konštrukcia podopretá kíbovo kotevnými tyčami modelovanými ako plné kruhové prierezy D46. Popísaný model môžeme vidiet' na Obr. 2 vl’avo.
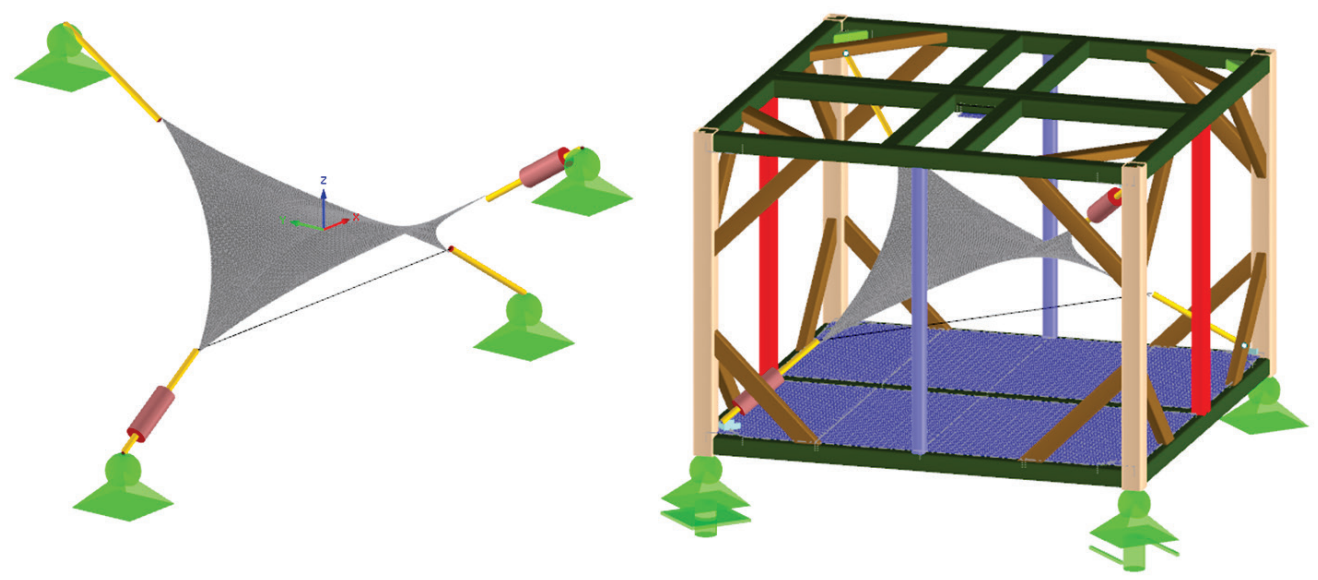

Obr. 2 1. variant - bez klietky (vl'avo), 2. variant - s klietkou (vpravo).

Uvedený model bol následne doplnený o ocel’ový rám, ktorý je opätovne súčast'ou reálneho zariadenia. Predstavuje tak 2. variant na porovnanie vlastného kmitania. Ide o uzatvorené profily štvorcového a obdížnikového tvaru (Obr. 2 vpravo) s celkovým rozmerom 3,34 ×3,34 × 2,5 m. Horná a dolná podstava je vytvorená pozváraním z profilov SHS140 $\times 140 \times 8$ a je po okrajoch spojená stĺpmi SHS160 $\times 160 \times 8$. V polovici podstáv sú doplňujúce stĺpiky RHS100 × $80 \times 60$ a SHS100 × $80 \times 6$. Rohy klietky sú vystužené šikmými profilmi RHS140 $\times 80 \times 6$.

Oba aktuálne popísané modely prešli dynamickou analýzou, konkrétne vlastným kmitaním. Na tento účel ponúka použitý softvér Dlubal RFEM aj prídavný modul RF DYNAM Pro [7]. Vlastné kmitanie v tomto prípade zahŕňa 1 hmotový stav od vlastnej tiaže konštrukcie ako stáleho zat’aženia. Výsledkom je taktiež 1 stav vlastného kmitania, v ktorom je nutné zohl'adnit' ešte pred vlastným kmitaním predopnutie membrány a to prostredníctvom 
procesu zvaného form-finding [8], ktorý je absolútne nevyhnutný a prebieha vždy ako prvý krok akejkol’vek simulácie. V uvažovaných modeloch bolo počítaných 10 vlastných tvarov s použitím Lanczosovej metódy na výpočet vlastných čísel a konzistentnej matice. Všetky výsledky získane touto analýzou sú podrobne prezentované v nasledujúcej časti.

\section{VÝSLEDKY}

Základné skúmané charakteristiky sú vlastná frekvencia, vlastná perióda a uhlová frekvencia. Pre potreby tohoto článku budú uvedené iba hodnoty vlastných frekvencií. Tieto výsledky sú prezentované na Obr. 3 formou grafu.

Taktiež je vhodné uviest' vykreslenie vlastných tvarov. Na Obr. 4 sú vyobrazené tvary kmitania pre prvé 3 vlastné tvary.

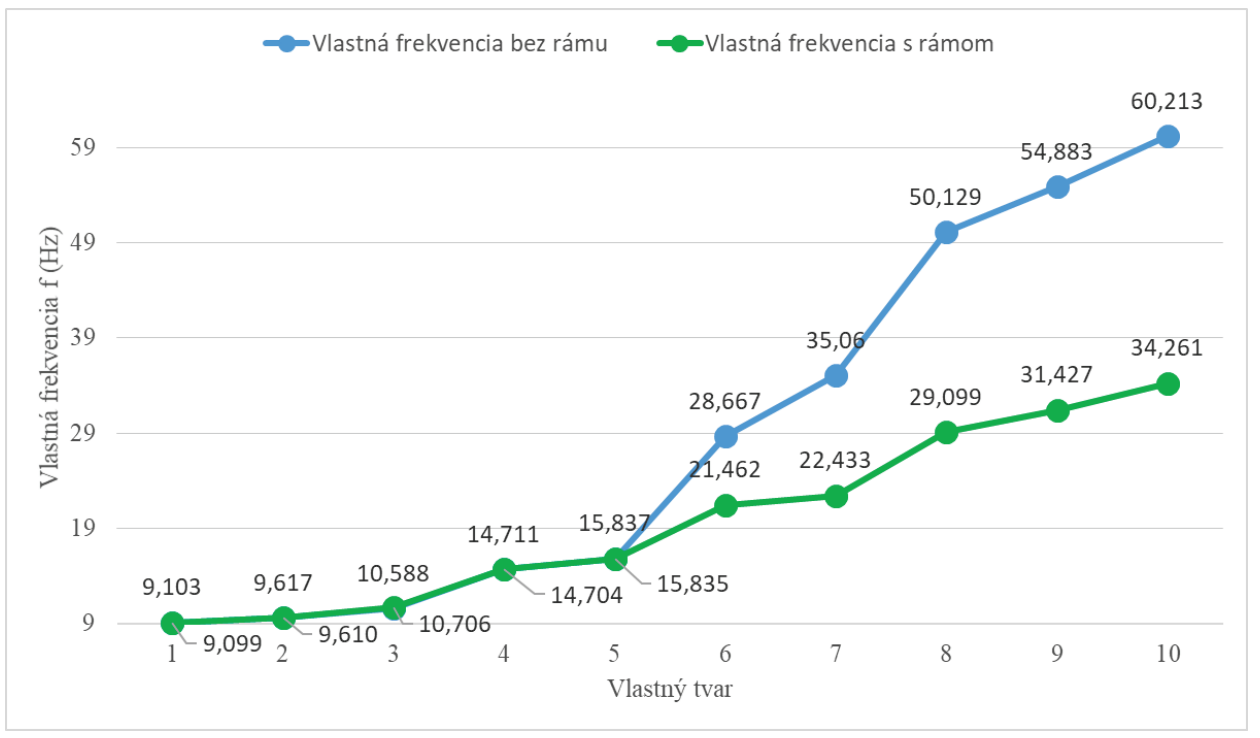

Obr. 3 Hodnoty vlastných frekvencií oboch variantov.
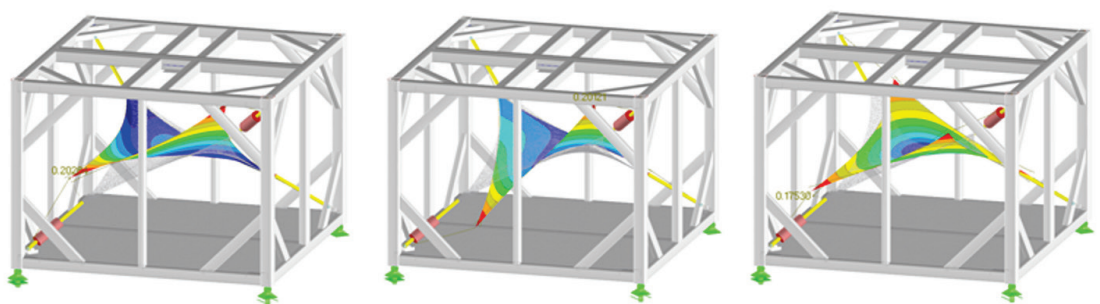

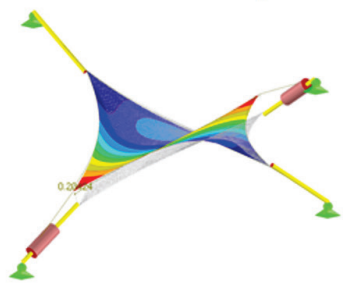

1. vlastný tvar

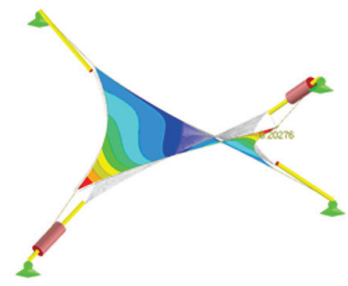

2. vlastný tvar

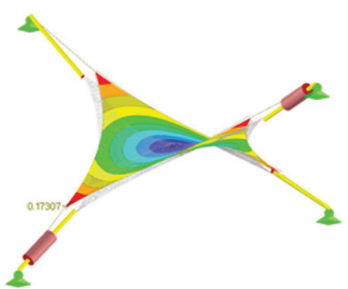

3. vlastný tvar

Obr. 4 Tvary vlastného kmitania. 


\section{DISKUSIA}

Na základe výsledkov stanovených modálnou analýzou môžeme vyvodit’ nasledujúce tvrdenia: s narastajúcim počtom vlastných tvarov narastá aj rozdiel medzi oboma variantmi. Môžeme však povedat', že na základe výsledkov v prvých 5 vlastných tvaroch nedochádza $\mathrm{k}$ takmer žiadnym rozdielom. Táto odchýlka je zároveň pre výsledky najdôležitejšia, pretože práve nižšie vlastné tvary majú najväčší vplyv na dynamickú analýzu. Z týchto rozdielov môžeme usúdit', že pridaná ocel'ová rámová konštrukcia je natol'ko tuhá, že nemení vlastné tvary ani vlastné frekvencie konštrukcie.

Prvotný predpoklad, že okrajové podmienky a primárna konštrukcia bude signifikantne menit’ výsledky tak nie je úplne potvrdená. Tento fakt je odôvodnený tuhost'ou ocel'ovej konštrukcie, ktorá sa vel'mi približuje všeobecným okrajovým podmienkam - dokonalému kĺbovému podopretiu.

Na základe zobrazenia vlastného kmitania prvých 3 vlastných tvarov môžeme vidiet', že aj samotné kmitanie je totožné pre prípad s kíbovými podperami a pre prípad s ocel'ovou klietkou. Čo však môžeme poznamenat' je, že v 2. vlastnom tvare došlo k zmene smeru vychýlenia so zachovaním symetrie.

Dôležitým parametrom pri navrhovaní konštrukcií sú aj výchylky a deformácie. Ako možno vidiet’ z Obr. 4, hodnoty deformácií sa pri prvých vlastných tvaroch rovnako nelíšia.

Posledný záver, ktorý možno vyvodit', sa týka hodnôt vlastných frekvencií. Ked’že na navrhovanom modeli bude prevedená dynamická analýza, ktorá má prezentovat' dynamické účinky klimatických zat’ažení ako napr. dynamického vetra, frekvencie do hodnoty $5 \mathrm{~Hz}$ (prípadne $10 \mathrm{~Hz}$ ), sú pre skúmanie najdôležitejšie. Naše hodnoty však nadobúdajú frekvencie tesne nad $9 \mathrm{~Hz}$, čo na skúmanie požadovaných účinkov môže byt' nedostatočné. Treba však mysliet' aj na fakt, že dané zariadenie je skúšobné a teda rozmery sú prispôsobené priestorovým požiadavkám v laboratóriu. Reálne konštrukcie tak bývajú navrhované v násobkoch rozmerov tejto skúmanej membránovej bunky a preto je nevyhnutné sa následne zamerat' na dynamické podobnosti, nakol'ko nejde o lineárne pomery medzi rozmermi, frekvenciami, tuhost'ami a hmotnost'ou.

\section{ZÁVER}

Ciel’om tejto práce bolo uskutočnit' na 2 modeloch modálnu analýzu vlastných tvarov. Dôvodom tejto numerickej analýzy bolo porovnanie vplyvu okrajových podmienok, konkrétne primárnej ocel'ovej konštrukcie, na tuhost' modelu a následne na výsledky vlastného kmitania.

Z výsledkov uvedených v predošlej kapitole bolo vyhodnotené, že konštrukcia v tomto prípade je dostatočne tuhá a nevplýva na získané výsledky pri prvých vlastných tvaroch, ktoré sú najpodstatnejšie z hl'adiska dynamickej analýzy.

Vlastná analýza je však stále iba prvým krokom dynamickej analýzy. V d’alšom výskume by mala nasledovat' dynamická analýza vynúteného kmitania - harmonicky premenné, periodické, neperiodické, tlmené či netlmené kmitanie.

Ked’že je spomínaný model založený na reálnom experimentálnom zariadení, je v neposlednom rade nutné tieto teoreticky získané výsledky na ňom overit'. Toto zariadenie je zat’ažované formou hydraulického valca umiestneného na hornej podstave ocel'ového rámu v jej geometrickom strede a vie vyvolávat' zat’aženia s určitým priebehom. Vynútené kmitanie simulované numericky tak môžeme potvrdit’ aj prakticky.

\section{Pod'akovanie}

Túto prácu podporila Agentúra na podporu výskumu a vývoja na základe zmluvy č. APVV-15-0777 a Slovenská vedecká grantová agentúra na základe zmluvy č. VEGA 1/0129/20.

\section{Použité zdroje}

[1] LIUA, Changjiang, Xiaowei DENG a Zhoulian ZHENG. Nonlinear wind-induced aerodynamic stability of orthotropic saddle membrane structures. Journal of Wind Engineering \& Industrial Aerodynamics. 2017, 2017(164), 119-127. ISSN 0167-6105.

[2] KANDEL, Arjun, Xiaoying SUN a Yue WUA. Wind-induced responses and equivalent static design method of oval-shaped arch-supported membrane structure. Journal of Wind Engineering \& Industrial Aerodynamics. 2012, 2021(213), 1-18. ISSN 0167-6105.

[3] TAKADATE, Yuki a Yasushi UEMATSU. Steady and unsteady aerodynamic forces on a long-span membrane structure. Journal of Wind Engineering \& Industrial Aerodynamics. 2019, 2019(193), 1-13. ISSN 0167-6105. 
[4] DAMERCHELOO, Ali Reza, Ahmad Reza KHORSHIDVAND, S. Mahdi KHORSANDIJOU a Mohsen JABBARI. Free vibrational characteristics of GNP-reinforced joined conical-conical shells with different boundary conditions. Thin-Walled Structures. 2021, 2021(169), 1-16. ISSN 0263-8231.

[5] WANG, X. H. a D. REDEKOP. Natural frequencies and mode shapes of an orthotropic thin shell of revolution. Thin-Walled Structures. 2005, 2005(43), 735-750.

[6] YIN, Yue, Wujun CHEN, Jianhui HU, Bing ZHAO a Qin WANG. In-situ measurement of structural performance of large-span air-supported dome under wind loads. Thin-Walled Structures. 2021, 2021(169), 1-11. ISSN 0263-8231.

[7] RF-DYNAM Pro-Natural Vibration Analysis, Response Spectra, Time History, Equivalent Static Forces: Program Description. Version January 2020. Tiefenbach, Germany: Dlubal Software, 2020.

[8] Stress-adapted numerical form finding of pre-stressed surfaces by the updated reference strategy. International Journal for Numerical Methods in Engineering. 2005, 64(2), 143-166. Dostupné z: doi:https://doi.org/10.1002/nme.1344 